\title{
Construction, transfection and production of recombinant vigilin in
}

\section{mammalian expression system}

\author{
Sayed Kamel Areida \\ Zoology Department, Faculty of Science, Mansoura University, Mansoura, Egypt.
}

\begin{abstract}
Vigilin is an abundant, highly conserved, ubiquitous protein containing 15 related, but non-identical, K-homolous nucleic acid binding domains. The construction, transfection and production of recombinant vigilin in mammalian expression system were investigated. The whole length of vigilin was amplified by polymerase chain reaction (PCR) and ligated to pCEPPU vector. The recombinant construct pCEP-PU with vigilin was produced and transfected into Human embryonic kidney cells in a specific culture medium. The secreted recombinant vigilin was purified from the serum-free medium to homogeneity by affinity chromatography. The conditioned and purified media were tested for the presence of vigilin by sodium dodecyl sulfate polyacrylamide gel electrophoresis (SDS-PAGE) and immunoblotting with specific antibody. An immunoreactive band with an apparent molecular mass of approximately $140 \mathrm{kDa}$ was detected. Immunofluorescence staining of transfected cells with vigilin demonstrated that recombinant vigilin molecules are localized in the nucleus and cytoplasm. In summary, the purified recombinant vigilin will facilitate future studies that address the structure and function of vigilin.
\end{abstract}

Keywords: SDS-PAGE / vigilin / Immunoblott / Immunofluorescence/ affinity chromatography

\section{Introduction}

Ribonucleoprotein complexes (RNPs) are substrates for RNA export from the nucleus to the cytoplasm (Siomi et al, 1994; kim et al, 1995) through nuclear pore complexes, an energy-dependent process which is mediated by specific saturable factors (Nandabalan and Roeder, 1995). These findings have stimulated efforts to identify RNA-binding proteins involved in RNA export. A number of RNA-binding motifs has been described in recent years, such as the RNP motif, the arginine-rich motif, the RGG box and the heterogenous nuclear ribonucleoprotein $\mathrm{K}$-homologous (KH) domain (Kiledjian et al, 1995). The multi-KH-protein vigilin has a nuclear localization sequence, and has been localized in the nucleus and cytoplasm of a wide variety of cells (Kuegler et al, 1996).

Analysis of the vigilin KH-domain structure has suggested that the protein consists of $15 \mathrm{KH}$ domains (Kruse et al, 1996), rather than the 14 domains described previously. The occurrence of an additional fifteenth N-terminal $\mathrm{KH}$ domain is supported by the observation that the exon/intron boundaries also define the structure of this domain, as observed for the remaining 14 domains (Lang and Fridovich-Keil, 2000). Since the KHdomain sequence motif is highly degenerate, and to avoid confusion with the numbering of the $14 \mathrm{KH}$ domains of vigilin described previously, the vigilin tRNA complex has only been characterized from a cytosolic extract (Kruse et al, 1998).

Although vigilin is an ubiquitous protein, it should be emphasized that highest expression is observed in those cells which are known to produce high quantities of protein, such as liver parenchymal cells or pancreatic secretory cells (Plenz et al,1993; Arning et al, 1996). From the increase of vigilin production in cells and tissues with stimulated translational activity, and owing to the fact that 
antivigilin antibodies may inhibit the synthesis of proteins during translation in vitro (Weber et al,1997; Kruse et al, 2000), it is reasonable to assume that vigilin may have a, as yet unknown, function in protein translation. The pesent study was designed to investigate the construction, transfection and production of recombanint vigilin in mammalian expression system as secreted protein.

\section{Materials and Methods}

\section{Recombinant expression plasmid of vigilin (pCEP-vigilin plasmid)}

Vigilin cDNA was amplified by polymerase chain reaction (Mullis et al, 1986) with sense primer and anti-sense primer. The amplification product was inserted into restricted expression vector pCEP-Pu (Kohfeldt et al., 1997).

\section{Transfection and Production of Recombinant vigilin}

Human embryonic kidney cells were cultivated in Dulbecco's modified Eagle medium containing $10 \%$ fetal calf serum, $0.25 \quad \mathrm{mg} / \mathrm{ml} \quad \mathrm{G} 418, \quad 0.1 \quad \mathrm{mg} / \mathrm{ml}$ penicillin/streptomycin, and $2 \mathrm{mM} \mathrm{L}$ Glutamine. The pCEP-vigilin plasmid (25 $\mu \mathrm{g}$ ) was transfected into cells (one million cells $/ 10 \mathrm{~cm}^{2}$ culture dish) using a calcium phosphate precipitation method (Chen and Okayama, 1987) and a selection period with $0.5 \mu \mathrm{g} / \mathrm{ml}$ puromycin.

\section{Purification of recombinant vigilin by affinity chromatography}

The serum-free cell culture media (three liters) containing recombinant vigilin was concentrated to $\sim 50 \mathrm{ml}$, and dialyzed. The dialyzate was loaded on a $\mathrm{Ni}^{2+}$ nitrilotriacetate superflow column. After being washed with 30 column vol. of wash buffer $\left[50 \mathrm{mM} \quad \mathrm{NaH}_{2} \mathrm{PO}_{4} \quad(\mathrm{pH} \quad 8.0) / 1 \mathrm{M}\right.$ $\mathrm{NaCl}]$ and 10 column vol. of wash buffer containing $40 \mathrm{mM}$ imidazole, the recombinant vigilin was eluted in the wash buffer containing $80 \mathrm{mM}$ imidazole.

\section{Western Blot (immunoblot) analysis}

Proteins were resolved on sodium dodecyl sulfate (SDS) polyacrylamide gels (Laemmli ,1970) and transferred onto nitrocellulose membrane ( $\mathrm{Li}$ et al, 1993). Membranes were incubated for $2 \mathrm{~h}$ in 10 $\mathrm{mM}$ Tris- $\mathrm{HCl}, \mathrm{pH} 8.0,150 \mathrm{mM} \mathrm{NaCl}$, $0.05 \%$ Triton X-100 (TBST) containing 15 $\%$ skim milk, rinsed with TBST, and then incubated over night with polyclonal antivigilin antiserum FPIII (1:1000 diluted) in TBST containing $0.1 \%$ bovine serum albumin (BSA). Membranes were washed three times with TBST, incubated with antirabbit immunglobulins conjugated with alkaline phosphatase (1:1000 diluted) in TBST including $0.1 \% \mathrm{BSA}$ for $1 \mathrm{~h}$ at room temperature. After incubation in $100 \mathrm{mM}$ Tris- $\mathrm{HCl}, \mathrm{pH} 9.5,100 \mathrm{mM} \mathrm{NaCl}$ and $5 \mathrm{mM}$ $\mathrm{MgCl}_{2}$ (AP-buffer) for $10 \mathrm{~min}$, protein bands were visualized by a color reaction with nitro blue tetrazolium/5-bromo-4chloro-3-indolyl phosphate dissolved in buffer until the bands were clearly visible.

\section{Immunofluorescence staining of transfected cells with vigilin}

The transfected human embryonic kidney cells with vigilin were grown in Iscoves medium, supplemented with $10 \%$ fetal-calf serum, $100 \mathrm{U} / \mathrm{ml}$ penicillin, 100 $\mu \mathrm{g} / \mathrm{ml}$ streptomycin, $0.05 \mathrm{mg} / \mathrm{ml} \mathrm{l-ascorbic}$ acid sodium salt and $2 \mathrm{mM}$ glutamine. Under these growth conditions briefly 2 $4 \times 10^{5}$ cells were grown on round cover slips ( $22 \mathrm{~mm}$ in diameter) for $48 \mathrm{~h}$, washed twice with phosphate buffered saline (PBS, $137 \mathrm{mM} \mathrm{NaCl}, 8.5 \mathrm{mM} \mathrm{Na} 2 \mathrm{HPO}_{4}, 1.5 \mathrm{mM}$ $\mathrm{KH}_{2} \mathrm{PO}_{4}, 3 \mathrm{mM} \mathrm{KCL}, \mathrm{pH}$ 7.3), fixed with methanol for $10 \mathrm{~min}$ and subsequently with acetone for $1 \mathrm{~min}$ at $-20{ }^{\circ} \mathrm{C}$. Cells were washed again twice with PBS. As primary antiserum and anti-vigilin antibody FPIII (dilution 1:200 in PBS containing $0.1 \%$ BSA) were applied for one hour at $37{ }^{\circ} \mathrm{C}$. For fluorescence staining of cells a Cy3 conjugated secondary anti-rabbit antiserum (dilution 1:400) combined with an AMCA conjugated secondary anti-human antiserum (dilution 1:100). 


\section{Sayed Kamel Areida}

\section{Results}

Construction and expression of recombinant vigilin

cDNA of vigilin was amplified by polymerase chain reaction (PCR) with sense primer 5'-CATGCCATGGGGAGTTCCGTTGCAGTTTTGACC-3' and anti-sense primer 5'-GAAGATCTTCGTTTGGGGCCCCAAGGGAG-3' in the presence of dNTPs and PCR buffer. The PCR amplification products were fractionated by gel electrophoresis using $0.8 \%$ agarose gel (Fig. 1). DNA band was visualized under ultraviolet light after staining with ethidium bromide (Fig. 1, lane 2). The NcoI-BglII fragment of the amplification product was inserted into the NcoI-BglII restricted expression vector pCEP-Pu containing the signal peptide sequence BM-40 and a Puromycine resistance gene (Fig. 2) resulting in plasmid pCEP-vigilin. This plasmid encodes 1266 amino acids residues (3800bp) which is identical to the whole length of vigilin. The plasmid pCEP-vigilin was resticted by specific enzymes to control the insert PCR fragment into vector (Fig. 3). The NcoIBglII restricted plasmid show two bands (Fig. 3A, lane 2) and NheI-NcoI-BgIII restricted plasmid show three bands (Fig. 3B and $\mathrm{C}$, lane 2). As negative control without restriction, the plasmid show no band (Fig. 3B, lane 3).

pCEP-vigilin plasmid was transfected into human embryonic kidney cells. The transfected cells were grown to confluence, washed twice with phosphate-buffered saline, and switched to serum-free medium. The media were collected every $48 \mathrm{~h}$, cooled, centrifuged to remove cellular debris.

\section{purification of recombinant vigilin}

The purification of recombinant vigilin was started with two liter of conditioned serum-free medium. After concentration and dialysis, the dailyzate was purified by affinity chromatography
(Fig. 4). All of contaminating proteins eluted at different positions. The elution profile recorded at $230 \mathrm{~nm}$ show elution fractions of vigilin from 1-5 (Fig. 4).

\section{Characterization of recombinant vigilin \\ A-SDS-PAGE and Immunobloting analysis of recombinant vigilin}

Before purification, the conditioned serum-free medium was tested for the presence of recombinant vigilin by SDS gel electrophoresis using coomassie blue staining and immunoblotting. Compared with nontransfected controls (Fig. 5A, lane 1), the transfected cells secreted approximately $2 \square \mathrm{g} / \mathrm{ml}$ of recombinant vigilin with an apparent molecular mass of $140 \mathrm{kDa}$ (Fig. 5A, lane2). The same recombinant fragment was identified in immunoblots with specific antibody against vigilin at the same molecular mass of 140 kDa (Fig. 6, lane2).

After purification, The elution fractions were tested for the presence of recombinant vigilin by SDS gel electrophoresis and stained with coomassie blue staining. About $40 \%$ of started protein was recovered and the final purity of highly purified recombinant vigilin was detected to be more than $95 \%$ (Fig. 5B, lanes 1-4). An immunoreactive band with an apparent molecular mass of approximately $140 \mathrm{kDa}$ (Fig. 6, lane3) was detected, while, no immunreactive product was detected in the preparations from control transfected cells (Fig. 6, lane1).

\section{B- Immunofluorescence staining analysis of recombinant vigilin}

Immunofluorescence staining served to study the localization of recombinant vigilin molecules in cytoplasm and nucleus of transfected cells (Fig. 7). Transfected cells were immunostained with antibody against vigilin indicating the localization of vigilin molecules in the cytoplasm and nucleus (Fig.7A). On the other hand, the nontransfected cells with vigilin did not show immunostained (Fig.7B) as a negative control. 
Fig. 1 Polymerase chain reaction (PCR) analysis. The PCR products demonstrated the full vigilin fragment $(3800 \mathrm{bp})$ in lane 2 . I kb ladder marker was run in lane 1.

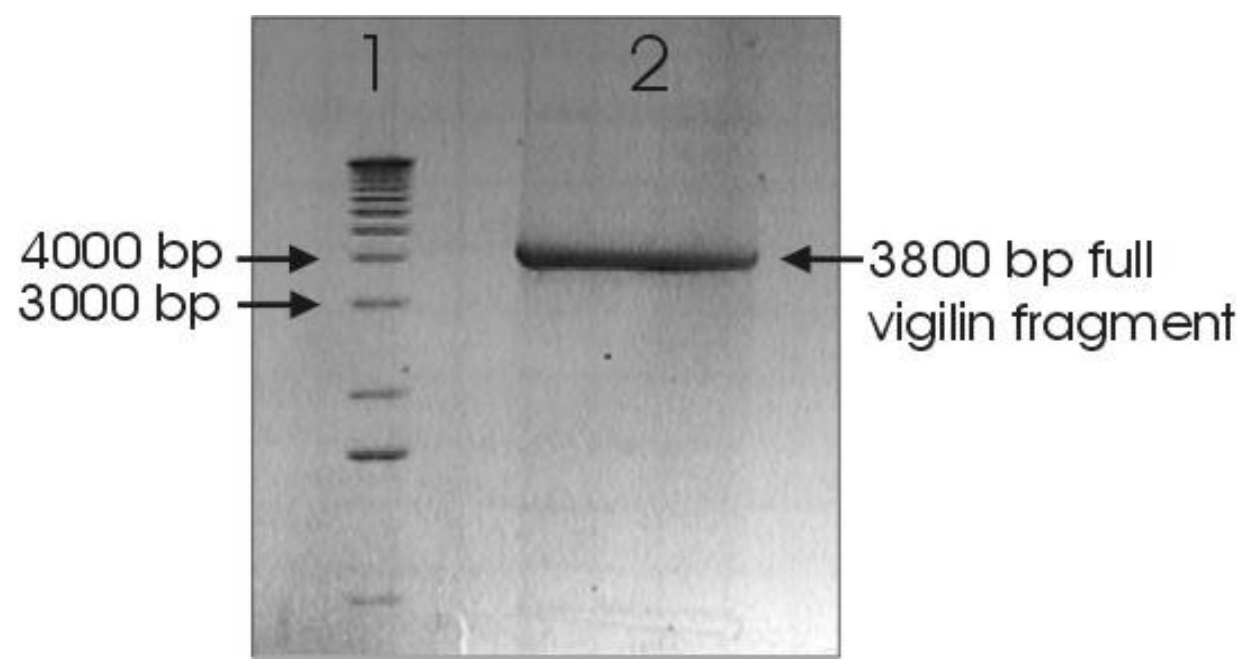

Fig. 2 Construction of recombinant vigilin plasmid. The PCR vigilin fragment was ligated into pCEP-PU vector resulting in pCEP-PU-vigilin plasmid.

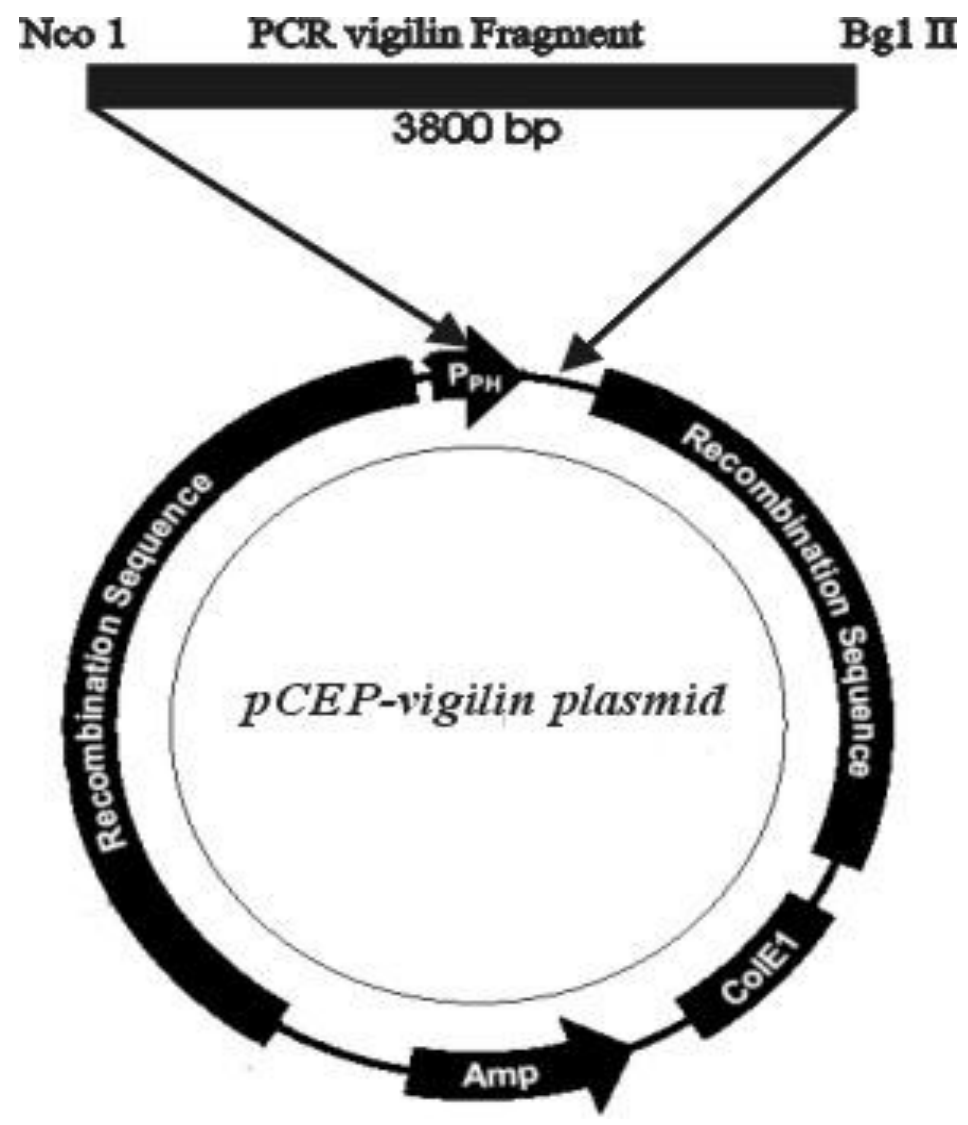




\section{Sayed Kamel Areida}

Fig. 3 The restriction endonucleases digestion of pCEP-PU-vigilin plasmid. Analysis on $0.8 \%$ agarose gel, the vigilin plasmid was digested with Nco I- BgI II (panel A; lane2), Nhe I- Nco I- BgI II (panel B; lane2 and panel C; lane2) and negative control without enzymes (panel B; lane3). I kb ladder marker for DNA shown in lane 1.
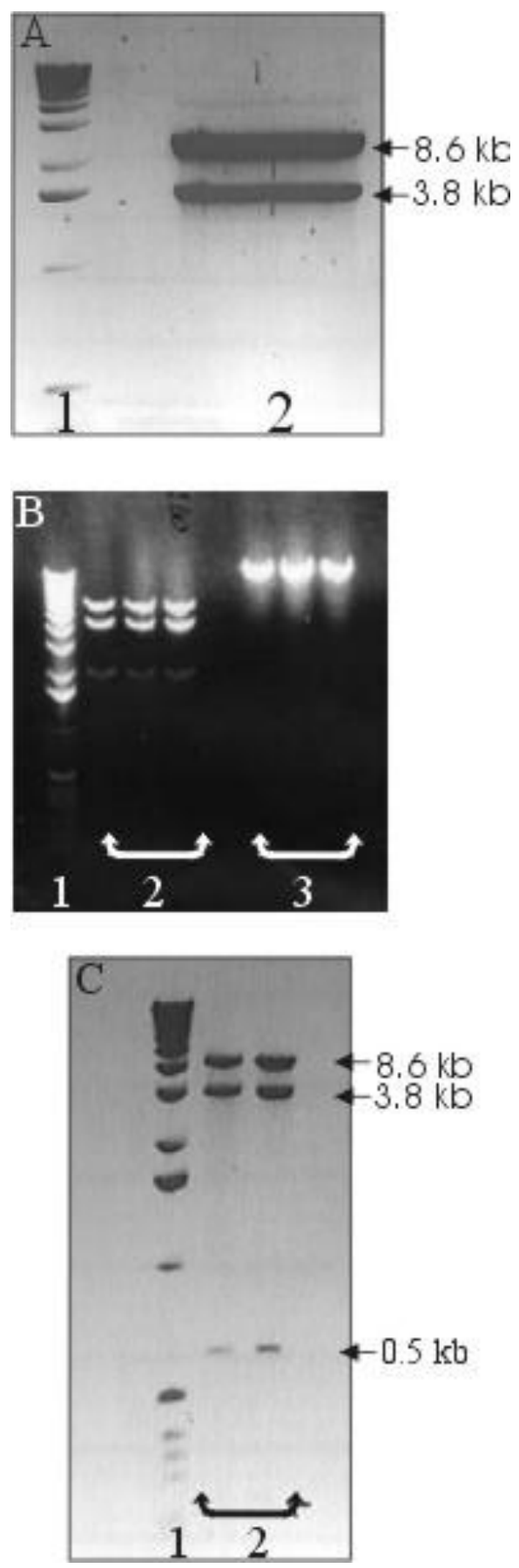
Fig. 4 Purification of secreted vigilin by affinity chromatography. The elution profile recorded at $230 \mathrm{~nm}$ shows the elution fractions of purified vigilin.

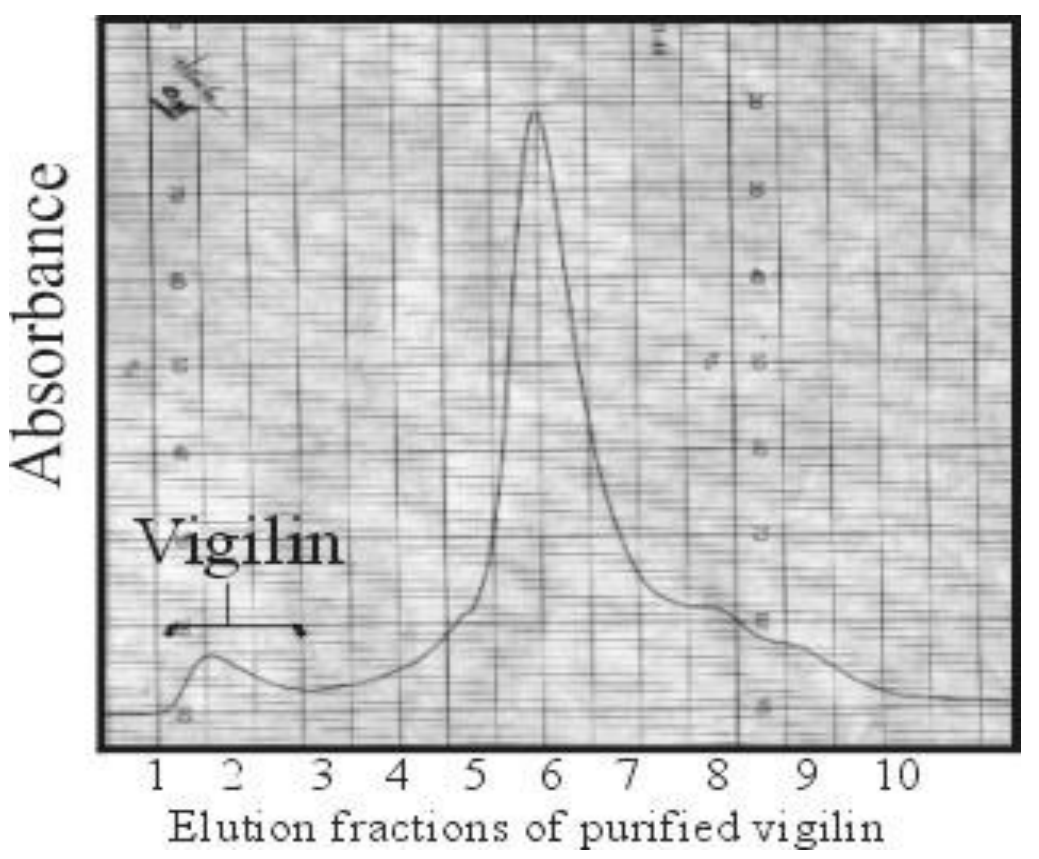

Fig. 5 SDS- polyacrylamide gel electrophoresis ( SDS-PAGE) analysis of recombinant vigilin. The secreted vigilin was purified, separated by SDS-PAGE and stained with Coomassie Blue. A and B, secreted vigilin before and after purification respectively. Control medium from nontransfected cells ((panel A; lane 1) and transfected cells with vigilin (panel A; lane2). Vigilin pattern after affinity chromatography (panel B; lanes 1-4). Positions of globular marker proteins are indicated in kDa.

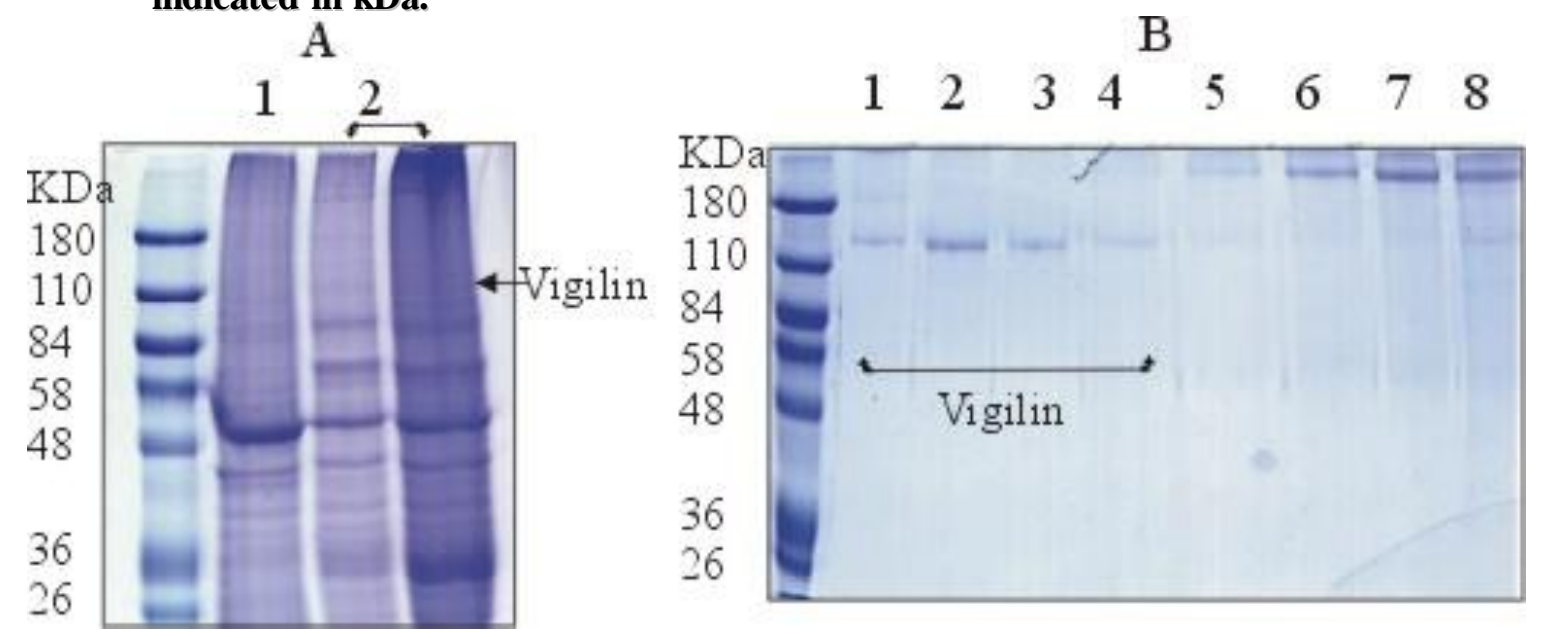




\section{Sayed Kamel Areida}

Fig. 6 Immunoblot analysis of secreted recombinant vigilin. The purified recombinant vigilin separated by SDS gel electrophoresis and electrotransferred to nitrocellulose membranes. The blot was incubated with first antibody against vigilin for $\mathbf{2}$ hrs and with second antibody for one hour. The conditional free media of secreted vigilin before purification shown in lane 2 and after purification in lane 3. Proteins marker indicated in $\mathrm{kDa}$ in lane 1.

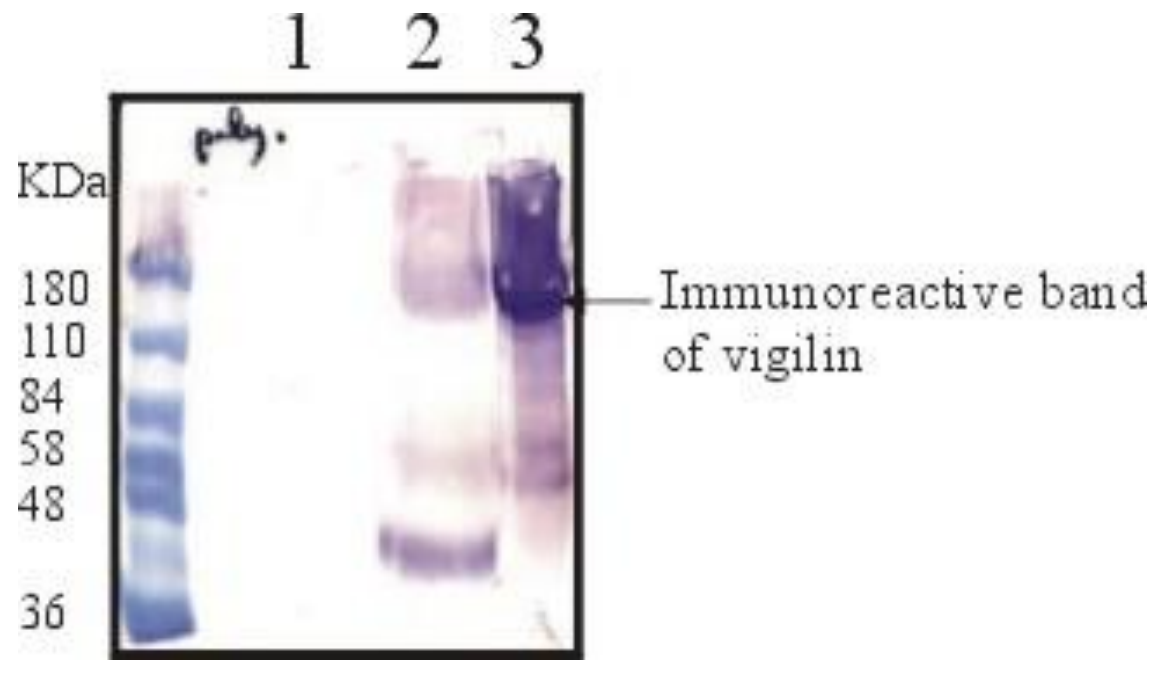

Fig. 7 Immunofluorescence microscopy of transfected cells with vigilin (A) and nontransfected cells (B) as negative control.

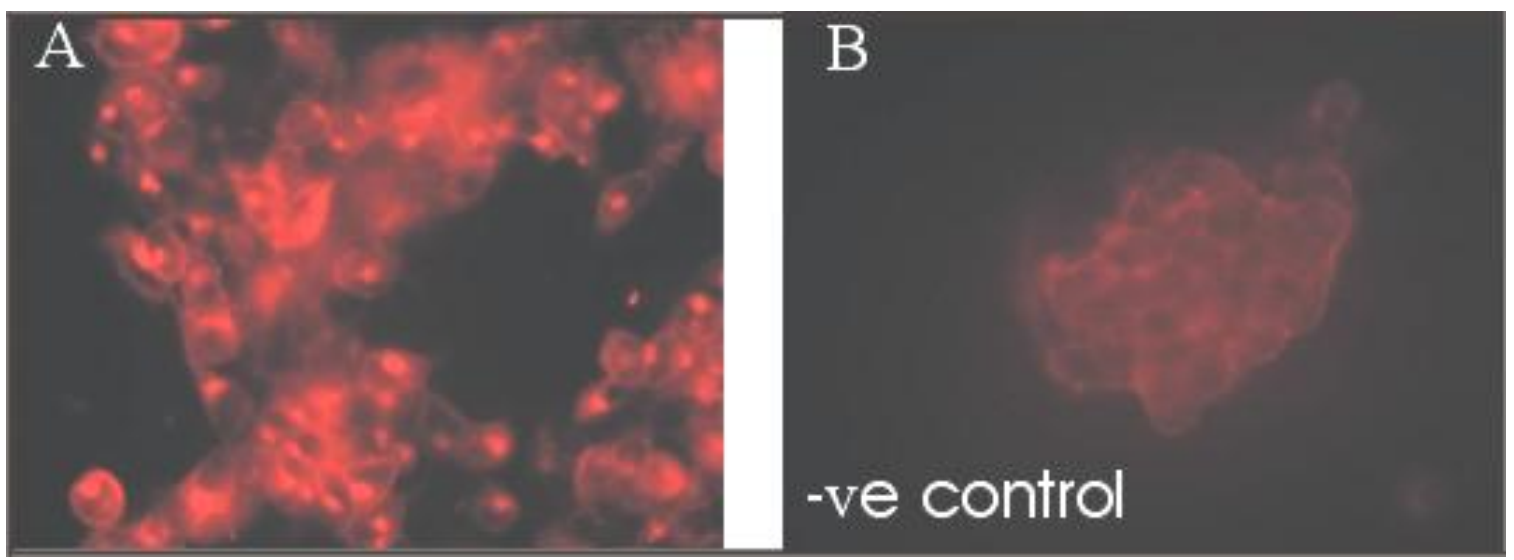

\section{Discussion}

Vigilin, a protein with 15 reiterative putative RNA-binding domains of the $\mathrm{KH}$ type (Dodsen and Shapiro, 1997), has been shown to be capable of binding RNA. The observation that vigilin is part of a nuclear as well as a cytoplasmic multi-protein tRNP (Kügler et al., 1996) suggested that one cellular function of the protein might be associated with tRNA binding and/or export. This idea was supported by the finding that cellular levels of vigilin are always highest under conditions of increased protein synthesis (Mahone et al., 1995), which imply a high demand for tRNA molecules.

Also, the isolated vigilin complexes are composed of a large number of polypeptides, they nevertheless satisfy several criteria of specificity. First, they have been isolated from soluble nuclear and cytoplasmic protein fractions by using 
affinity-purified anti-vigilin antibodies, yielding highly reproducible protein patterns with different immuno-affinity matrix preparations and different batches of soluble protein fractions from HEp-2 cells (Schmidt et al., 2002). Secondary, such complexes resist treatment with high salt concentrations $(0.8-1.0 \mathrm{M} \mathrm{NaCl})$, which releases the bound tRNA.

The prescnce of 14-1S KH-domains is a distinct structural feature of vigilins since other $\mathrm{KH}$-proteins in general contain only 1-S KH-domains. Also, the presence of KH-domains in such numbcrs as seen in vigilin could $b c$ the reason of a variety at first glance contradictory interaction profiles with different RNA species (Weber et al., 1997). Looking at the motif alignment in vigilin and other $\mathrm{KH}$-proteins shows evident that the tight consecutive arrangement of the 14/I S KH-domains is exceptional as is the localization of both the NLS and NES at unique sitcs within the KH-domains.

A central question is concerned with which protein components of the cytoplasmic and nuclear vigilin-containing tRNPs physically interact with tRNA. Vigilin itself may, in part, fulfil this role, owing to its tandemly repeated $\mathrm{KH}$ domains, which have been shown to bind RNA in other proteins. This question was addressed by analysing the binding of radioactive vigilin translated in vitro to biotinylated tRNA immobilized on streptavidin-coated magnetic beads (Dodson and Shapiro, 1997). Specificity of tRNA-binding is suggested by competition experiments, since the presence of excess free tRNA over immobilized tRNA inhibited reproducibly vigilin binding to the immobilized tRNA. Thus, the evidence that vigilin may be able to bind a cellular RNA, namely tRNA, which is in line with structural investigations (Draper et al., 2001) which predict an RNA-binding surface on the vigilin $\mathrm{KH}$ domain. However, these results do not rule out the possibility that vigilin and other components of our immunoafinity-purified vigilin complexes may interact with tRNA (Kruse et al., 2000). The prominent 140 $\mathrm{kDa}$ protein band found to be enriched in both the cytoplasmic and the nuclear vigilin complexes. In conclusion, These experimental strategy of expressing the vigilin as a secreted recombinant protein should facilitate future studies that address the structure and function of this protein.

\section{Acknowledgements}

I thank Drs Mueller P.K, Kruse C and Notbohm $\mathrm{H}$ for the pCEP-Pu expression vector, cDNA of vigilin and for help and advice concerning the Human expression system. I also acknowledge the technical assistances of Department of Medical Molecular Biology, Germany.

\section{References}

1. Arning, S., Gruter, P., Bilbe, G. and Kramer, A. (1996). Mammalian splicing factor SF1 is encoded by variant cDNAs and binds to RNA.RNA. 2, 794-810. Chen, C., and H. Okayama (1987). HighEfficiency Transformation of mammalian cells by plasmid DNA. Mol. Cell Biol., 7, 8: $2745-2752$.

2. Dodson, R. and Shapiro, J. (1997).Vigilin, a ubiquitous protein with 14 $\mathrm{K}$ homology domains, is the estrogeninducible vitellogenin mRNA 3'untranslated region-binding protein. J. Biol. Chem. 272, 12249-12252.

3. Draper, B.W., Mello, C.C., Bowermann, B., Hardin, J. and Priess, J.R. (2001). MEX-3 is a $\mathrm{KH}$ domain protein that regulates blastomere identity in early $\mathrm{C}$. elegans embryos.Cell. 87, 205-16.

4. Kiledjian, M., Wang, X. and Liebhaber, S.A. (1995). Identification of two $\mathrm{KH}$ domain proteins in the $\alpha$-globin mRNP stability complex. EMBO J. 14, 4357-4364.

5. Kim, J., Chubatsu, L.S., Admon, A., Strahl, J., Fellous, R. and Linn, S. (1995). Implication of mammalian ribosomal protein S3 in the processing of DNA damage. J. Biol. Chem. 270, 13620-13629.

6. Kohfeldt, E., P. Maurer, C. Vannahme, and R. Timpl (1997). Properties of the extracellular calcium binding module of the proteoglycan testican. FEBS Lett., 414 (3): 557-561.

7. Kruse, C., Grünweller, A., Notbohm, H., Kügler, S., Purschke, W. and Müller, P.K. (1996). Evidence for a novel 


\section{Sayed Kamel Areida}

cytoplasmic tRNA-protein complex containing the $\mathrm{KH}$-multidomain protein vigilin. Biochem. J. 320, 247-252.

8. Kruse, C., Grünweller, A., Willkomm, D.K., Pfeiffer, T. and Hartmann, R.K. (1998). tRNA is entrapped in similar, but distinct, nuclear and cytoplasmic ribonuleoprotein complexes, both of witch contain vigilin and elongation factor $1 \alpha$. Biochem. J. 329, 615-621.

9. Kruse, C., Willkomm, D.K., Grünweller, A., Vollbrandt, T., Sommer, S., Busch, S., Pfeiffer, T., Brinkmann, J., Hartmann, R.K. and Müller, P.K. (2000). Export and transport of tRNA are coupled to a multi-protein complex. Biochem. J. 346, 107-115

10. Kuegler, S., Grünweller, A., Probst, C., Klinger, M., Müller, P.K., and Kruse, C. (1996). Vigilin contains a functional nuclear localisation sequence and is present in both the cytoplasm and the nucleus. FEBS Lett. 382, 330-334.

11. Laemmli, U. K. (1970). Cleavage of structural proteins during the assembly of the head of bacteriophage T4. Nature 227 (25): 680-685.

12. Lang, B.D. and Fridovich-Keil, J.L. (2000). Scp160p, a multiple KH-domain protein, is a component of mRNA complexes in yeast. Nucleic Acids Res. 28, 1576-1584.

13. Li, K., K. Tamai, E. M. Tan, and J. Uitto. (1993). Cloning of type XVII collagen. Complementary and genomic DNA sequences of mouse 180-kilodalton Bullous Pemphigoid Antigen (BPAG2) predict an interrupted collagenous domain, a transmembrane segment, and unusual features in the 5'-end of the gene and the 3'untranslated region of the mRNA. J. Biol Chem., 268 (12): 8825-8834.

14. Mahone, M., Saffman, E.E. and Lasko, P.F. (1995). Localized Bicaudal-C RNA encodes a protein containing a $\mathrm{KH}$ domain, the RNA binding motif of FMR1. EMBO J. 14, 2043-2055

15. Mullis, K.B., Faloona,F.A., and Horn G.T (1986). Pecific enzymatic amplification of DNA in vitro: the polymerase chain reaction. Cold Spring Harbor Symp Quant Bio. 51:263-273.

16. Nandabalan, K. and Roeder, G.S. (1995). Binding of cell-type-specific RNA splicing factor to its target regulatory sequence. Mol. Cell. Biol. 15, 1953-60

17. Plenz, G., Gan, Y., Raabe, H.M. and Müller P.K. (1993). Expression of vigilin in chicken cartilage and bone. Cell Tissue Res. 273, 381-389.

18. Schmidt, C., Henkel, B., Pöschl, E., Purschke, W., Gloe, T.R. and Müller, P.K. (2002). Complete cDNA sequence of chicken vigilin, a novel protein with amplified and evolutionary conserved domains. Eur. J. Biochem. 206, 625-634.

19. Siomi, H., Choi, M., Siomi, M.C., Nussbaum, R.L. and Dreyfuss, G. ( 1994). Essential role for $\mathrm{KH}$ domains in RNA binding: Impaired RNA binding by a mutation in the $\mathrm{KH}$ domain of FMR1 that causes fragile X syndrome. Cell 77, 33-39.

20. Weber, V., Wernitzing, A., Hager, G., Harata, M., Frank, P. and Wintersberger, U. (1997). Purification and nucleic-acid-binding properties of a Saccharomyces cerevisiae protein involved in the control of ploidy. Eur. J. Biochem. 249, 309-17.

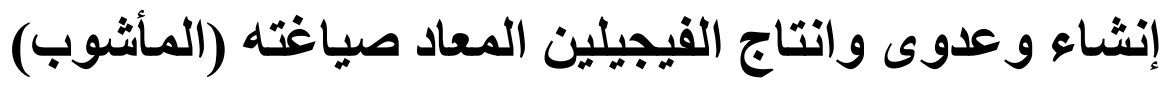




\title{
فى أوساط زراعة الأنسجة فى الثييات
}

\author{
السيد كامل عريضه \\ مصر المنصورة -جامعة المنصورة -قسم علم الحيوان -كلية العلوم
}

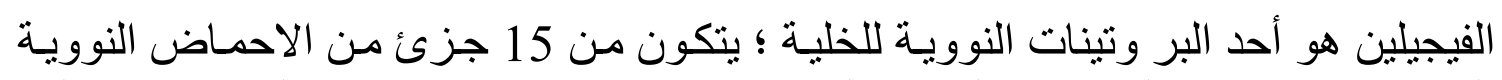

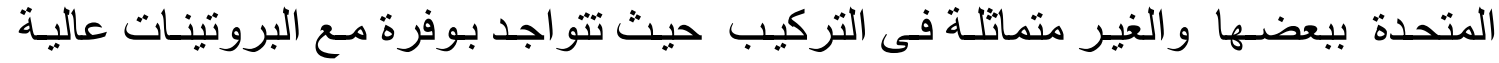

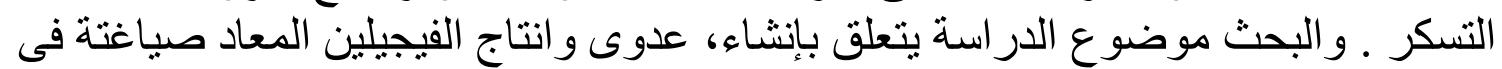
أوساط زر اعة الانسجة في الثذييات. وقد تم تضخيم التتابع الكلى للأحماض الألى الأمينية للفيجيلين بإستخدام سلسلة تفاعل أنزيم

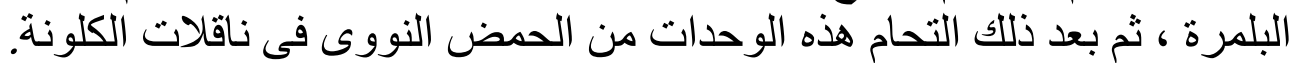

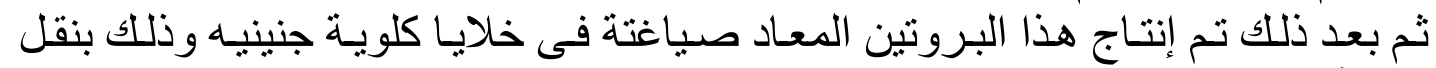

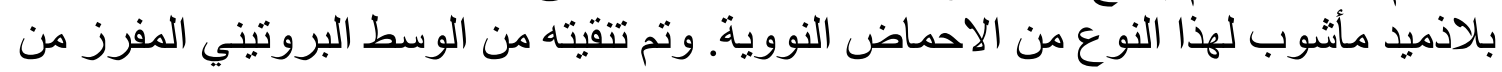

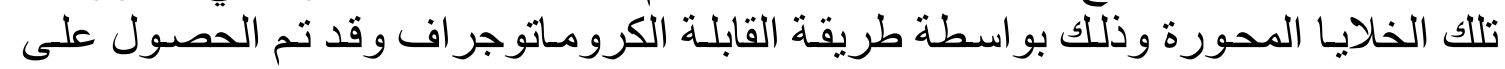

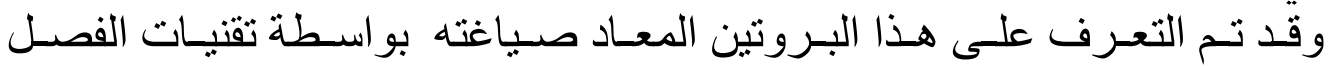

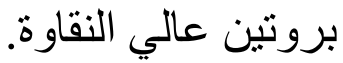

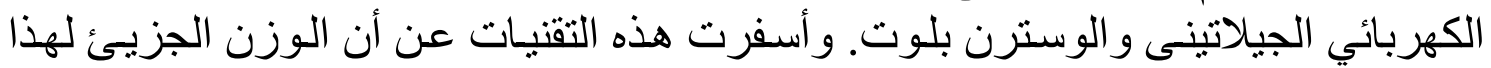

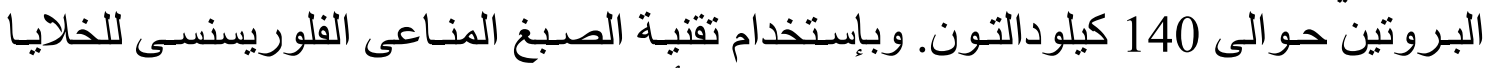

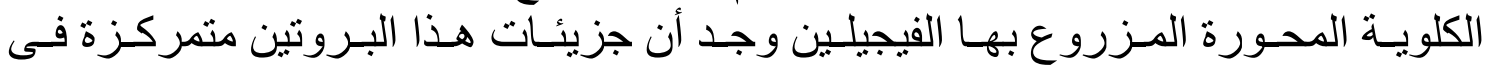
السيتوبلازم و النواة لهذه الخلايا.

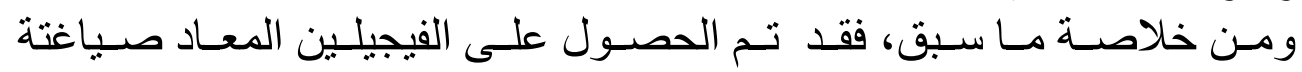
(المأثوب) فى صورة نقية مما يسهل الدراسات المستقبلة علية من حيث التركيب و الوظيفة. 